\title{
Discussion on product oil on-line back mixing technology based on a product oil pipeline
}

\author{
Kaihong $\mathrm{Li}^{1}$, Liang Feng ${ }^{1,}{ }^{*}$, Rui Zhang ${ }^{1}$, and Wenjun Dang ${ }^{2}$ \\ ${ }^{1}$ PipeChina Southwest Company, 610094 Chengdu, China \\ ${ }^{2}$ PipeChina West to east Company, 200000Shanghai, China
}

\begin{abstract}
The mixed oil treatment of Product oil is an important task of pipeline enterprises. The paperconcluded that the on-line back mixing technology was feasible, compared treatment methods from the perspective of safety and economic benefits. TheProduct oil pipeline is taken as the research object in this paper, studied the concentration distribution of mixed Product oil and amount of mixed Product oilunder operation and shutdown condition, and brief studied Product oil On-line back mixing technology. Combined with the demand and pipeline length, the mixing test is determined at CD station and CQ station. The operation process as follow: First, Product oilsamples areextracted from the pipeline. Second, the index parameters are detected after the oil samples are mixed with different proportions, and obtaining the blending potential under the theoretical situation, the result show that the mixing potential of gasoline is greater than that of diesel. Third, the field test do with arbitrarily mixed oil download scheme, which study two mixed oil surfaces. The required fund of dealing with the mixed oil is obtained combined with the download amount of mixed oil.Finally, comparing with the funds of the previous contaminated treatment methods, it is concluded that the On-line Back Mixing technology has great advantages in both safety and economic benefits.
\end{abstract}

\section{Research background}

The causes of mixed oil in the batch transportation of product oil pipeline mainly include convection-diffusion (convection transfer, flow velocity extension), molecular diffusion and turbulent diffusion in turbulent state ${ }^{[1]}$. Turbulent diffusion is caused by the irregular motion of particles, and only exists in the turbulent motion ${ }^{[2]}$.

At present, many scholars at domestic and abroad have studied the amount of mixed oil. Austin and Palfrey obtained the Austin-Palfrey empirical formula,which does not consider the influence of transportation sequence on the mixing oil $^{[3]}$.Ms. Huang reviewed the research status of oil mixing amount in the sequential transportation of product oil pipelines with variable diameter at domestic and abroad, and analyzed the influence of variable diameter on oil mixing amount ${ }^{[4]}$. Zhang and $\mathrm{Wu}$ et al. show that the oil mixing characteristics change with the change of oil output in the subsequent rows, and the change

\footnotetext{
* Corresponding author: fenglangtc@126.com
} 
rules are different in different periods ${ }^{[5]}$. In this paper, a product oil pipeline is taken as the research object, and the research content is mainly to obtain the maximum blending ratio of diesel and gasoline by mixing oil samples at CD station and CQ station. The mixed oil download scheme (only two mixed oil surfaces are studied) is selected for field test, and the requirements for processing this part of the mixed oil are obtained by combining the mixed oil download amount.

\section{Introduction to the test}

The total length of LCY product oil pipeline is $1250 \mathrm{~km}$, which uses closed transportation technology to transport No. 92 and No. 0 diesel, with an annual output of $700 \times 10^{4}$ t. There are 16 process stations in the whole line, and the maximum design pressure is $14.76 \mathrm{MPa}$. In addition, there are three communication and instrument rooms for high point pressure detection. The pipeline design annual output (350d) LZ-CD $700 \times 10^{4} \mathrm{t}$, CD-CQ $350 \times 10^{4} \mathrm{t}$, $\mathrm{PZ}$ injection branch $100 \times 10^{4} \mathrm{t}$. The maximum operating pressure of each station entrance and exit station should be at least $0.5 \mathrm{MPa}$ lower than the set pressure relief value.

\subsection{Sampling and Testing of Pure Oil Samples from CD Station}

The sampling work in this experiment was carried out at CD station and CQ station. The sampling results of No.92 gasoline and No.0 diesel oil in CD station are shown in tables 1 and 2.

Table 1. Sampling results of No. 92 gasoline in CD station

\begin{tabular}{ccccc}
\hline $\begin{array}{c}\text { Experimental } \\
\text { times }\end{array}$ & $\begin{array}{c}\text { Density of gasoline } \\
\text { working } \\
\text { conditionkg/m }\end{array}$ & $\begin{array}{c}\text { Density of standard } \\
\text { condition } \mathrm{k} / \mathrm{m}^{3}\end{array}$ & Pressure kPa & Temperature ${ }^{\circ} \mathrm{C}$ \\
\hline 1 & 736.4 & 740.3 & 95.1 & 23.9 \\
2 & 736.4 & 740.3 & 95.1 & 23.9 \\
3 & 736.4 & 740.3 & 95.1 & 23.9 \\
Average value & 736.4 & 740.3 & 95.1 & 23.9 \\
\hline
\end{tabular}

Table 2. Sampling results of No.0 diesel oil from CD station

\begin{tabular}{ccccc}
\hline $\begin{array}{c}\text { Experimental } \\
\text { times }\end{array}$ & $\begin{array}{c}\text { Density of diesel } \\
\text { working } \\
\text { conditionkg/m }\end{array}$ & $\begin{array}{c}\text { Density of } \\
\text { standard condition } \\
\mathrm{kg} / \mathrm{m}^{3}\end{array}$ & Pressure kPa & Temperature ${ }^{\circ} \mathrm{C}$ \\
\hline 1 & 821.1 & 823.7 & 95.1 & 23.7 \\
2 & 821.1 & 823.7 & 95.1 & 23.7 \\
3 & 821.1 & 823.7 & 95.1 & 23.8 \\
Average value & 821.1 & 823.7 & 95.1 & 23.7 \\
\hline
\end{tabular}

\subsection{The configuration and test of standard mixed oil samples}

The mixed oil standard samples are configured according to different volume ratios. The experimental results of the mixed oil samples are shown in tables 3 and 4.According to GB 19147-2016 Diesel fuel for vehicles, when the flash point of the mixed oil sample reaches $62^{\circ} \mathrm{C}$, the gasoline volume ratio contained in the oil sample is the maximum mixing potential of diesel under the experimental conditions. Experimental data reference table 3. 
Table 3. The mixing ability test experiment of No. 0 diesel oil in CD station

\begin{tabular}{|c|c|c|c|c|c|c|c|c|c|}
\hline \multirow{2}{*}{$\begin{array}{l}\text { Gasoline } \\
\text { concentrati } \\
\text { on in } \\
\text { mixed oil }\end{array}$} & \multicolumn{2}{|c|}{$\begin{array}{l}\text { Density of mixed } \\
\text { oil sample } \\
\mathrm{kg} / \mathrm{m}^{3}\end{array}$} & \multicolumn{2}{|c|}{$\begin{array}{l}\text { Standard density } \\
\text { of oil sample } \\
\mathrm{kg} / \mathrm{m}^{3}\end{array}$} & \multicolumn{2}{|c|}{$\begin{array}{c}\text { End point } \\
\text { of oil } \\
\text { sample }{ }^{\circ} \mathrm{C}\end{array}$} & \multirow[t]{2}{*}{$\begin{array}{l}\text { Atmos } \\
\text { phere } \\
\text { pressur } \\
\text { ekPa }\end{array}$} & \multirow[t]{2}{*}{$\begin{array}{l}\text { Correcti } \\
\text { on } \\
\text { temperat } \\
\text { ure }^{\circ} \mathrm{C}\end{array}$} & \multirow[t]{2}{*}{$\begin{array}{c}\text { Correct } \\
\text { ion } \\
\text { flash } \\
\text { point }^{\circ} \\
\text { C } \\
\end{array}$} \\
\hline & 1 & 2 & 1 & 2 & 1 & 2 & & & \\
\hline $0.00 \%$ & 821.1 & 821.1 & 823.7 & 823.7 & 66 & 66 & 95.1 & +1.55 & 67.5 \\
\hline $0.10 \%$ & 821.0 & 821.0 & 823.6 & 823.6 & 64 & 64 & 95.1 & +1.55 & 65.5 \\
\hline $0.20 \%$ & 820.9 & 820.9 & 823.5 & 823.5 & 63 & 63 & 95.1 & +1.55 & 64.5 \\
\hline $0.30 \%$ & 820.8 & 820.8 & 823.4 & 823.4 & 61 & 61 & 95.1 & +1.55 & 62.5 \\
\hline $0.40 \%$ & 820.8 & 820.7 & 823.4 & 823.3 & 59 & 59 & 95.1 & +1.55 & 60.5 \\
\hline $0.50 \%$ & 820.7 & 820.7 & 823.3 & 823.3 & 57 & 57 & 95.1 & +1.55 & 58.5 \\
\hline $0.60 \%$ & 820.2 & 820.3 & 819.8 & 819.9 & - & - & 95.1 & +1.55 & - \\
\hline
\end{tabular}

According to Table 3 , when the gasoline volume ratio in the mixed oil sample is $0.30 \%$, the corrected flash point is $62.5^{\circ} \mathrm{C}$. According to GB $17930-2016$ Automotive gasoline, when the final distillation point of the mixed oil sample reaches $203^{\circ} \mathrm{C}$, the diesel volume ratio contained in the oil sample is the maximum mixing potential of gasoline under the experimental conditions.Experimental data reference table 4.

Table 4. Test experiment on mixing ability of No. 92 gasoline at CD station

\begin{tabular}{|c|c|c|c|c|c|c|c|c|c|}
\hline \multirow{2}{*}{$\begin{array}{c}\text { Diesel } \\
\text { concentrat } \\
\text { ion in } \\
\text { mixed oil }\end{array}$} & $\begin{array}{c}\text { Density of mixed } \\
\text { oil sample } \\
\mathrm{kg} / \mathrm{m}^{3}\end{array}$ & \multicolumn{2}{|c|}{$\begin{array}{c}\text { Standard density } \\
\text { of oil sample } \\
\mathrm{kg} / \mathrm{m}^{3}\end{array}$} & \multicolumn{2}{|c|}{$\begin{array}{c}\text { End point of oil } \\
\text { sample }{ }^{\circ} \mathrm{C}\end{array}$} & $\begin{array}{c}\text { Atmosp } \\
\text { here } \\
\text { pressur } \\
\mathrm{ekPa}\end{array}$ & $\begin{array}{c}\text { Corre } \\
\text { ction } \\
\text { temp } \\
\text { eratu } \\
\text { re }{ }^{\circ} \mathrm{C}\end{array}$ & $\begin{array}{c}\text { Corre } \\
\text { ction } \\
\text { end } \\
\text { point } \\
\mathrm{C}\end{array}$ \\
\hline $0.00 \%$ & 736.4 & 736.4 & 739.9 & 739.9 & 190.0 & 189.0 & 95.1 & +2.4 & 192.0 \\
$0.50 \%$ & 736.8 & 736.8 & 740.3 & 740.3 & 200.0 & 199.0 & 95.1 & +2.4 & 202.0 \\
$1.00 \%$ & 737.2 & 737.2 & 740.7 & 740.7 & 215.0 & 215.0 & 95.1 & +2.4 & 217.5 \\
$1.50 \%$ & 737.7 & 737.7 & 741.2 & 741.2 & - & - & 95.1 & +2.4 & - \\
\hline
\end{tabular}

According to the data in Table 4,when the diesel volume ratio in the mixed oil sample is $0.50 \%$, the corrected final distillation point reaches $202{ }^{\circ} \mathrm{C}$. Combined with the final distillation point control standard of gasoline to be sold in the group, it is concluded that the mixing potential of No. 92 gasoline at CD station is $0.50 \%$ under the batch.

\subsection{Oil sampling and testing experiment at $C Q$ terminal station}

The sampling method of pure oil at CQ station was consistent with that at CD station. After sampling, the flash point and final distillation point of pure oil were tested, respectively. The results are shown in Table 5 and Table 6.

Table 5. Parameter test of No.92 gasoline sample in CQ station

\begin{tabular}{ccccccc}
\hline $\begin{array}{c}\text { Experimen } \\
\text { tal times }\end{array}$ & $\begin{array}{c}\text { Density of } \\
\text { working } \\
\text { conditionkg/ } \\
\mathrm{m}^{3}\end{array}$ & $\begin{array}{c}\text { Density of } \\
\text { standard } \\
\text { conditionkg/ } \\
\mathrm{m}^{3}\end{array}$ & $\begin{array}{c}\text { End } \\
\text { point }^{\circ} \\
\mathrm{C}\end{array}$ & $\begin{array}{c}\text { Atmosphe } \\
\text { re } \\
\text { pressure } \\
\mathrm{kPa}\end{array}$ & $\begin{array}{c}\text { Correction } \\
\text { temperature } \\
{ }^{\circ} \mathrm{C}\end{array}$ & $\begin{array}{c}\text { Correcti } \\
\text { on end } \\
\text { point }^{\circ} \mathrm{C}\end{array}$ \\
\hline 1 & 741.9 & 742.8 & 190 & 95.1 & 2.5 & 192.5 \\
2 & 741.9 & 742.8 & 189 & 95.1 & 2.5 & 191.5 \\
3 & 741.9 & 742.8 & 191 & 95.1 & 2.5 & 193.5 \\
Average & 741.9 & 742.8 & 190 & 95.1 & 2.5 & 192.5 \\
\hline
\end{tabular}


Table 6. Parameter test of No.92 diesel sample in CQ station

\begin{tabular}{ccccccc}
\hline $\begin{array}{c}\text { Experiment } \\
\text { al times }\end{array}$ & $\begin{array}{c}\text { Density of } \\
\text { working } \\
\text { conditionkg/ } \\
\mathrm{m}^{3}\end{array}$ & $\begin{array}{c}\text { Density of } \\
\text { standard } \\
\text { conditionkg/ } \\
\mathrm{m}^{3}\end{array}$ & $\begin{array}{c}\text { Flash } \\
\text { point } \\
\mathrm{C}\end{array}$ & $\begin{array}{c}\text { Atmosphe } \\
\text { re } \\
\text { pressure } \\
\mathrm{kPa}\end{array}$ & $\begin{array}{c}\text { Correction } \\
\text { temperature } \\
{ }^{\circ} \mathrm{C}\end{array}$ & $\begin{array}{c}\text { Correcti } \\
\text { on flash } \\
\text { point }{ }^{\circ} \mathrm{C}\end{array}$ \\
\hline 1 & 826.9 & 829.3 & 64 & 95.1 & 1.55 & 65.5 \\
2 & 826.9 & 829.3 & 64 & 95.1 & 1.55 & 65.5 \\
3 & 826.9 & 829.3 & 64 & 95.1 & 1.55 & 65.5 \\
Average & 826.9 & 829.3 & 64 & 95.1 & 1.55 & 65.5 \\
\hline
\end{tabular}

The experimental results of Table 5 and Table 6 show that the final distillation point of No.92 gasoline at CQ station is $192.5^{\circ} \mathrm{C}$, which is $0.5^{\circ} \mathrm{C}$ lower than that at $\mathrm{CD}$ station. The flash point for No. 0 diesel is $65.5^{\circ} \mathrm{C}$, which is $2.0^{\circ} \mathrm{C}$ lower than that at $\mathrm{CD}$ station.From the above results, during the transportation of oil from CD to CQ station, the index parameters of No.0 diesel oil decreased greatly, and the index parameters of No.92 gasoline decreased less.

\section{Mixed oil analysis of product oil pipeline sequential transportation}

From the actual production experience, it can be seen that there is a great difference in the amount of mixed oil produced under the operation condition and the shutdown condition when the product oil is transported in sequence.

Assuming that the switching time of the oil in the product pipeline is $t_{1}$, at this point, as shown in Figure 1, the oil B on the left side of the initial contact surface is $100 \%$, and the oil $\mathrm{A}$ on the right side is also $100 \%$. On the starting contact surface, assuming that half of the oil A and half of the oil B, as shown in Fig. 1( a ).After a period of oil migration, when the oil reaches ${ }^{t_{2}}$, a section of mixed oil with length will be formed on both sides of the initial contact surface $\mathrm{O}$. Section $\mathrm{O}$ is still $K_{A}=K_{B}=0.5$ as shown in Fig. 1 ( b ). When the oil reaches the time ${ }^{t_{3}}$, the mixing section increases to 2 times of $l_{2}$, and the length of the mixing section on both sides of the contact surface is $l_{2}$, as shown in Fig 1 ( c ).

\begin{tabular}{ll|lll}
$K_{A}=0 \quad K_{z}=1$ & $K_{A}=0.5$ & $K_{z}=0.5$ & $K_{A}=1$ & $K_{z}=0$ \\
\hline B oil & & A oil \\
\hline & & \\
\hline & (a) $t_{1}$ &
\end{tabular}

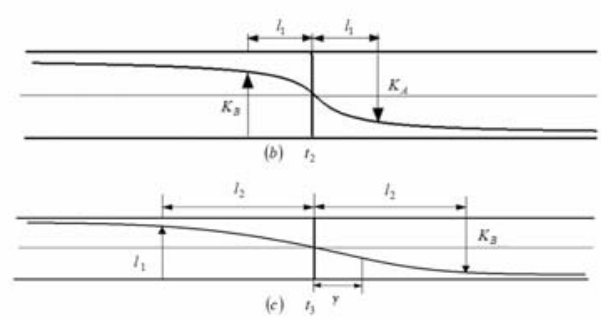

Fig. 1. Variation curve of concentration and length of mixed oil along pipeline

\section{Field test}

The current contaminated treatment method for LCY product oil pipeline is to unload the mixed oil at CQ station, and then pull the mixed oil to PZ refinery ( near CD station ) for 
reprocessing. The mixed oil download scheme (only two mixed oil surfaces are studied) is selected for field test. The scheme is to determine that after the mixed oil reaches the CD station, the mixed oil is downloaded for half an hour in the middle section, and the remaining mixed oil is downloaded at the CQ station.

At the interface of diesel pushing gasoline, about $124 \mathrm{~m}^{3}$ mixed oil was downloaded from CD station, and about $325 \mathrm{~m}^{3}$ from CQ station. The total amount of mixed oil in this batch was $449 \mathrm{~m}^{3}$, which was completely consistent with the fitting results of historical data of diesel pushing gasoline mixed oil. At the interface between gasoline and diesel,about $148 \mathrm{~m}^{3}$ mixed oil was downloaded from CD station, and about $280 \mathrm{~m}^{3}$ from CQ station. The total amount of mixed oil in this batch was $428 \mathrm{~m} 3$, which was completely consistent with the fitting results of historical mixed oil data of gasoline and diesel.After comparison and calculation, almost all of the mixed oil of the two interfaces are mixed back. Compared with the contaminated treatment method of the previous CQ station, it saves a lot of cost and avoids the possible danger of mixed oil in the transportation process.

\section{Conclusion}

This paper mainly describes oil sampling experiment and the experimental results of configuration experiment of standard mixed oil sample of LCY product oil pipeline.The conclusions are as follows:

(1) It can be concluded that the mixing potential of No. 92 gasoline in this batch is large, and the concentration of mixed diesel oil is $0.5 \%$. The mixing potential of No.0 diesel is small, and the mixed gasoline concentration is $0.3 \%$.

(2) It can be concluded that the batch of No.92 gasoline was transported from CD station to CQ station, and the change of index parameters is small. No. 0 diesel is transported from CD station to CQ station, and the oil index parameters decreased greatly. Download the middle section of the mixed oil in CD station, and the fitting results of the total amount of the downloaded mixed oil compared with the historical mixed oil data remain unchanged, so the mixed oil production in CD-CQ section is less.

The oil analysis is the key to realize online back mixing. At present, oil analysis is completed by manual sampling. It is suggested to introduce online monitoring technology from abroad, or to carry out research on this subject to realize localization.

\section{Reference}

1. Pujianing. Some problems in analysis of mixed oil in pipeline sequential transportation. Oil and gas storage and transportation (12): 18

2. Deng Songsheng, PuJianing. Application of convection diffusion equation in the analysis of mixed oil in the sequential transportation of refined oil. Applied Mathematics and mechanics, 08: 50-57, (1998)

3. Ann, C, Austin, et al. Mutagenicity of the fractionated organic emissions from diesel, cigarette smoke condensate, coke oven, and roofing tar in the ames assay.

4. Huang Shu Nu, Yang Cheng Han. Calculation of mixed oil volume with variable pipe diameter for sequential transportation of oil products. Oil and gas storage and transportation, 09: 33-35 + 5, (2005)

5. Zhang Ning, Wu Ming, Hu Zhiyong, et al. The influence of later oil transportation on the sequential transportation of mixed oil. Journal of Liaoning University of petroleum and chemical technology, (02): 54-57, (2013) 